\title{
Serapan Zat Besi Dalam Minuman Teh Kemasan Menggunakan Spektrofotometer
}

\author{
Iwan Sariyanto \\ Jurusan Analis Kesehatan Politeknik Kesehatan Tanjungkarang
}

\begin{abstract}
Abstrak
Anemia defisiensi besi merupakan masalah gizi yang paling lazim di dunia dan diderita lebih dari 600 juta manusia. Perkiraan prevalensi anemia secara global sekitar 51\%. Anemia defisiensi besi lebih cenderung berlangsung di negara sedang berkembang dari pada negara yang sudah maju. Hal itu berakar pada asupan yang tidak adekuat. Anemia kekurangan zat besi dapat disebabkan oleh konsumsi besi yang kurang atau dikonsumsi bersamaan dengan zat yang dapat menghambat serapan besi. Teh merupakan minuman yang banyak bermanfaat sebagi antioksidan, tetapi juga mempunyai zat anti gizi tanin yang dapat menghambat penyerapan besi apabila dikonsumsi dalam waktu yang tidak tepat. Penelitian ini bertujuan untuk mengetahui serapan zat besi (Fe) dalam minuman teh kemasan yang beredar dipasaran. Jenis penelitian ini bersifat ekperimental dengan menambahkan larutan Fe 1\% kedalam minuman teh kemasan. Pengukuran serapan Fe menggunakan methode spektrofotometri. Hasil penelitian yang dilakukan pada 10 macam minuman teh kemasan menunjukkan bahwa seluruh minuman teh kemasan menyerap larutan Fe 1\% dengan intensitas yang berbeda.Teh kemasan TG merupakan teh yang menyerap Fe paling sedikit yaitu sebesar 3,72 ppm. Sedangkan teh kemasan MT yang menyerap Fe paling banyak yaitu sebesar 37,08 ppm.
\end{abstract}

Kata kunci: Spektrofotometer, Teh kemasan, Zat besi

\section{Iron Absorption in Tea Drinks Packaging Using a Spectrophotometer}

\begin{abstract}
Iron deficiency anemia is the most common nutritional problem in the world and affects more than 600 million people. Estimates of anemia prevalence globally around 51\%. Iron deficiency anemia is more likely to occur in developing countries than in developed countries. This is rooted in inadequate intake. Iron deficiency anemia can be caused by lack of iron consumption or taken together with substances that can inhibit iron absorption. Tea is a drink that is useful as an antioxidant, but also has tannin anti-nutrients that can inhibit iron absorption when consumed in an inappropriate time. This study aims to determine iron (Fe) uptake in packaged tea drinks in the market. This type of research is experimental by adding a $1 \% \mathrm{Fe}$ solution to the packaged tea drink. Measurement of Fe uptake using the spectophotomteri method. The results of research carried out on 10 kinds of packaged tea drinks showed that all packaged tea drinks absorb $1 \%$ Fe solution with different intensities. TG packaging tea is the tea which absorbs the least amount of Fe, which is $3.72 \mathrm{ppm}$. While MT packaging tea absorbs the most $\mathrm{Fe}$, which is equal to $37.08 \mathrm{ppm}$.
\end{abstract}

Keywords: Iron, Spectrophotometer, Tea packaging

Korespondensi : Iwan Sariyanto, Jurusan Analis Kesehatan Politeknik Kesehatan Tanjungkarang, Jalan Soekarno Hatta No.1 Bandar Lampung, Mobile Phone: 08127938215, e-mail: iwansariyanto@poltekkes-tjk.ac.id 


\section{Pendahuluan}

Makanan mengandung berbagai macam zat gizi yang sangat dibutuhkan oleh tubuh untuk menjaga kesehatan. Semakin banyak jenis makanan yang dikonsumsi maka semakin kecil kemungkinan terserang penyakit tertentu. Konsumsi pangan oleh seseorang atau sekelompok orang bertujuan memenuhi kebutuhan fisiologis, psikologis dan sosiologis. Tujuan fisiologis adalah upaya untuk memenuhi keinginan makan (rasa lapar) atau untuk memperoleh zat-zat gizi yang diperlukan tubuh. Tujuan psikologis untuk memenuhi kepuasan emosional atau selera, sedangkan tujuan sosiologis untuk memelihara hubungan manusia dalam keluarga dan masyarakat. Pangan merupakan kebutuhan dasar manusia yang pemenuhannya menjadi hak asasi setiap rakyat Indonesia seperti yang tertuang dalam Undang undang Nomor 7 Tahun 1996 tentang pangan. Namun demikian, jumlah penduduk rawan pangan di Indonesia masih tinggi, Menurut data BPS tahun 2009, asupan kalori kurang dari $1400 \mathrm{Kkal}$ per orang dalam seharinya mencapai $14,47 \%$. Aksesibilitas pangan yang rendah mengancam penurunan konsumsi makanan yang beragam, bergizi seimbang dan aman ditingkat rumah tangga. Hal ini akan menyebabkan masalah kekurangan gizi pada masyarakat (Dewi C dan Mustika NH, 2012).

Indonesia saat ini dihadapkan dengan masalah gizi ganda, yaitu masalah gizi kurang dan masalah gizi lebih. Masalah gizi kurang pada umumnya disebabkan oleh kemiskinan; kurangnya persediaan pangan; kurang baiknya kualitas lingkungan (sanitasi); dan adanya daerah miskin gizi (iodium). Sebaliknya masalah gizi lebih disebabkan oleh kemajuan ekonomi pada lapisan masyarakat tertentu disertai dengan kurangnya pengetahuan tentang gizi, menu seimbang, dan kesehatan (Almatsier, 2009).

Keadaan kesehatan gizi masyarakat tergantung pada tingkat konsumsi. Tingkat konsumsi ditentukan oleh kualitas serta kuantitas hidangan. Kualitas hidangan menunjukkan adanya semua zat gizi yang diperlukan tubuh didalam susunan hidangan dan perbandingannya yang satu terhadap yang lain. Kuantitas menunjukkan kuantum masingmasing zat gizi terhadap kebutuhan tubuh. Konsumsi yang menghasilkan kesehatan gizi yang sebaik-baiknya disebut konsumsi adekuat. Jika susunan hidangan memenuhi kebutuhan tubuh , baik dari sudut kualitasnya dan dalam jumlah melebihi kebutuhan tubuh, dinamakan konsumsi berlebih, maka akan terjadi suatu keadaan gizi lebih. Sebaliknya konsumsi yang kurang baik kualitasnya maupun kuantitasnya akan memberikan kondisi kesehatan gizi kurang atau kondisi defisiensi (Soegeng, 2009).

Sesuai dengan masalah gizi masyarakat yang telah dikemukakan, maka ada empat penyakit defisiensi gizi yang dianggap sudah mencapai kegawatan nasional dikarenakan kerugian yang mungkin ditimbulkannya terhadap pembangunan manusia. Secara nasional ada empat masalah gizi utama di Indonesia yaitu :1) penyakit kekurangan kalori dan protein (KKP atau PEM, CPM), 2) penyakit defisiensi vitamin A, 3) penyakit defisiensi jodium (Iodine deficiency deseases, IDD) dan 4) penyakit anemia defisiensi zat besi $(\mathrm{Fe})$ (Soegeng, 2009).

Anemia gizi disebabkan oleh defisiensi zat besi, asam folat, dan/ atau vitamin $\mathrm{B}_{12}$, yang kesemuanya berakar pada asupan yang tidak adekuat, ketersediaan hayati rendah, dan kecacingan yang masih tinggi. Anemia defisiensi zat besi merupakan masalah gizi yang paling lazim didunia dan menjangkiti lebih dari 600 juta manusia. Perkiraan prevalensi anemia secara global sekitar 51\%. Anemia defisiensi besi lebih cenderung berlangsung di negara sedang berkembang daripada negara yang sudah maju.Tiga puluh enam persen (atau kirakira 1400 juta orang) dari perkiraan populasi 3800 juta orang di negara sedang berkembang menderita anemia jenis ini, sedangkan prevalensi di negara maju hanya sekitar $8 \%$ ( sekitar100 juta orang ) dari perkiraan populasi 1200 juta orang (Arisman, 2004).

Anemia kekurangan zat besi pada anakanak di Arab Saudi dan di Inggris juga dilaporkan berhubungan dengan kebiasaan minum teh (Gibson, 1999). Dilaporkan juga bahwa dampak dari interaksi teh dengan zat besi ini bergantung pada status konsumsi zat besi dan karakteristik individu (Makara, Kesehatan, Juni 2007: 38-43).

Makanan yang banyak mengandung zat besi adalah makanan yang berasal dari daging hewan. Akan tetapi, pada kenyataannya sebagian besar penduduk di negara berkembang belum mampu mengonsumsi makanan tersebut setiap hari dikarenakan keterbatasan ekonomi. Pada umumnya, tanpa disadari masyarakat mempunyai kebiasaaan mengonsumsi zat yang dapat menghambat penyerapan zat besi seperti teh pada saat yang bersamaan dengan makan, sehingga penyerapan besi menjadi terhambat. Hambatan penyerapan besi ini disebabkan oleh 
kandungan tanin yang terdapat di dalam teh (Almatsier, 2009).

Kebiasaan minum teh juga sudah menjadi budaya di beberapa negara dunia dan merupakan minuman yang paling banyak dikonsumsi oleh selain air putih, dengan ratarata konsumsi $120 \mathrm{~mL} /$ hari per kapita. Hampir seluruh dunia mengenal teh. Teh sudah menjadi komoditi dunia. Negara penghasil utama teh pun mengkonsumsi secara besarbesaran. Teh memiliki banyak manfaat bagi tubuh karena mengandung polifenol yang berpotensi sebagai antioksidan yang mampu melindungi tubuh dari radikal bebas. Potensi antioksidan teh lebih kuat dibandingkan dengan antioksidan yang terdapat pada buah-buahan dan sayur-sayuran. Beberapa manfaat teh yang telah diketahui antara lain menurunkan kolesterol, menurunkan risiko osteoporosis, sebagai antivirus, penghilang bau, menjaga kesehatan gigi dan mulut, meningkatkan kondisi kognitif dan psikomotor pada orang dewasa, mencegah penggumpalan darah, mencegah penyakit jantung koroner, mencegah penyakit liver, serta mencegah pertumbuhan dan perkembangan kanker, terutama kanker lambung, esofagus, dan kulit (Besral dkk, 2007).

Meskipun teh diketahui memiliki banyak manfaat untuk kesehatan, tetapi teh juga diketahui dapat menghambat penyerapan zat besi jika dikonsumsi pada waktu yang salah, seperti pada saat makan atau dalam satu jam setelah makan. Penghambatan penyerapan ini terjadi karena salah satu jenis polifenol yang terkandung di dalam teh tersebut, yaitu tanin. Kebiasaan inilah yang menjadi salah satu penyebab terjadinya anemia defisiensi besi. (Almatsier, 2009)

Nelson dan Poultert telah melakukan studi literatur bahwa teh hitam dapat menghambat penyerapan besi non hem sebesar 79-94\% jika dikonsumsi bersama-sama, penyerapan besi nonhem jika dikonsumsi dengan air putih sebesar $10-13 \%$, sedangkan jika dikonsumsi bersamaan dengan teh sebanyak $200 \mathrm{~mL}$ penyerapannya hanya sebesar $2-3 \%, 150 \mathrm{~mL}$ teh hitam yang dikonsumsi dalam satu jam setelah makan akan menurunkan penyerapan besi $75-80 \%$, dan teh hitam menghambat penyerapan besi hampir dua kali lipat daripada teh hijau (Nelson dan Poultert, 2004: 43-54). Penelitian yang dilakukan oleh Wardiyah H dkk (2014) didapatkan bahwa terdapat penyerapan atau penurunan absorban dari teh hijau sebanyak $32,34 \%$ dan teh hitam sebanyak $43,15 \%$ setelah penambahan larutan $\mathrm{FeCl}_{3} \quad 1 \%$ secara invitro.

Dewasa ini di seluruh pelosok Indonesia aneka produk teh dijumpai dalam kehidupan sehari-hari. Hampir semua jenis rumah makan, bakso, mie ayam atau restoran-restoran cepat saji menyajikan kedua produk teh tersebut. Oleh karena itu, permintaan dari konsumen yang semakin banyak untuk meminta minumannya teh botol, maka untuk tidak mengecewakan pelanggan akhirnya mereka memasukan produk minuman tersebut kedalam daftar minuman yang dapat dipesan.

Penelitian ini bertujuan untuk mengetahui serapan zat besi dalam minuman teh kemasan menggunakan spektrofotometer.

\section{Metode}

Penelitian ini bersifat eksperimental. Penelitian ini dilakukan di Laboratorium Kimia Jurusan Analis Kesehatan Politeknik Kesehatan Tanjungkarang pada bulan Mei hingga September 2018. Sampel dalam penelitian ini adalah 10 merk minuman teh kemasan yang paling sering diminum oleh responden. Responden sebanyak 50 orang yang berasal dari masyarakat sekitar Poltekkes. Setelah mendapatkan 10 merk minuman teh kemasan, sampel dibeli dari pasar swalayan terlengkap. Penetapan kadar Fe pada penelitian ini dengan methode Fenantrolin dan diukur serapannya menggunakan spektrofotometer uvvis. Kadar Fe awal sebesar 40 ppm. Selanjutnya dilakukan penambahan minuman teh dalam kemasan dan diukur kembali kadar Fe sisa atau yang terlarut, sehingga didapatkan kadar $\mathrm{Fe}$ yang bereaksi dengan minuman teh tersebut.

\section{Hasil}

\section{A. Analisis Univariat}

Tabel 1. Serapan teh kemasan paling sedikit dan paling banyak pada larutan $\mathrm{Fe}$

\begin{tabular}{cccccc}
\hline No & Kode & \multicolumn{2}{c}{$\begin{array}{c}\text { Serapan teh } \\
\text { kemasan } \\
\text { paling sedikit }\end{array}$} & \multicolumn{2}{c}{$\begin{array}{c}\text { Serapan teh } \\
\text { kemasan } \\
\text { paling banyak }\end{array}$} \\
\cline { 3 - 6 } & ppm & $\%$ & ppm & $\%$ \\
\hline 1 & TG & 3,72 & 9,3 & & \\
\hline 2 & MT & & & 37,08 & 92,7 \\
\hline
\end{tabular}

Berdasarkan tabel 1 tersebut didapatkan bahwa teh yang menyerap atau beraksi dengan Fe paling sedikit adalah teh TG yaitu sebesar $3,72 \mathrm{ppm}$. Sedangkan teh yang menyerap atau 
beraksi dengan Fe paling banyak adalah teh MT sebesar 37,08 ppm.

\section{B. Analisis Bivariat}

Analisis bivariat digunakan untuk mengetahui perbedaan serapan $\mathrm{Fe}$ terhadap berbagai minuman teh kemasan. Analisis bivariat yang digunakan uji ANOVA untuk mengetahui apakah terdapat perbedaan serapan Fe pada berbagai minuman teh kemasan.

Tabel 2. Distribusi kadar Fe yang diserap oleh minuman teh dalam kemasan

\begin{tabular}{cccccc}
\hline Kode & Mean & SD & \multicolumn{2}{c}{$\mathbf{9 5 \%}$ CI } & $\begin{array}{c}\text { P } \\
\text { value }\end{array}$ \\
\hline NG & 32,28 & 0,2280 & 31,997 & 32,562 & 0,0005 \\
FT & 30,48 & 0,1095 & 30,344 & 30,616 & \\
SS & 25,72 & 0,2280 & 25,437 & 26,003 & \\
JV & 33,52 & 0,7014 & 32,649 & 34,391 & \\
IO & 28,44 & 0,1673 & 28,232 & 28,648 & \\
TK & 24,72 & 0,2280 & 24,437 & 25,003 & \\
TG & 3,72 & 0,1789 & 3,498 & 3,942 & \\
PH & 12,96 & 0,1673 & 12,752 & 13,168 & \\
TH & 28,48 & 0,2280 & 28,197 & 28,763 & \\
MT & 37,08 & 0,1095 & 36,988 & 37,216 & \\
\hline
\end{tabular}

Berdasarkan hasil uji statistik $\mathrm{p}$ value $=$ 0,0005, dengan demikian terdapat perbedaan serapan $\mathrm{Fe}$ terhadap berbagai minuman teh kemasan

\section{Pembahasan}

Penetapan kadar Fe pada penelitian ini dengan methode Fenantrolin dan diukur serapannya menggunakan spektrofotometer uvvis. Kadar Fe awal diketahui dari perhitungan yaitu sebesar $40 \mathrm{ppm}$. Selanjutnya dilakukan penambahan minuman teh dalam kemasan dan diukur kembali kadar Fe sisa atau yang terlarut, sehingga didapatkan kadar Fe yang bereaksi dengan minuman teh tersebut.

Seluruh teh kemasan yang diuji terbukti menyerap larutan $\mathrm{Fe}$ yang ditambahkan pada minuman tersebut. Intensitas penyerapan $\mathrm{Fe}$ terhadap minuman teh tersebut berbeda pada setiap minuman teh kemasan. Berdasarkan jumlah serapan $\mathrm{Fe}$ pada minuman teh, teh TG merupakan teh yang paling sedikit menyerap larutan Fe, sedangkan teh MT merupakan teh yang banyak serapannya terhadap Fe.

Penyerapan ini terjadi disebabkan adanya senyawa polifenol dalam minuman teh salah satunya adalah senyawa tannin yang berikatan dengan senyawa logam $\mathrm{Fe}$ dan membentuk senyawa kompleks. Ketika reaksi koordinasi antara ion logam dan molekul organik yang memiliki sepasang elektron maka molekul organik tersebut akan mengikat ion logam. Hal tersebut sebagaimana pendapat Hallberg L and Hutten L, (2000) karena adanya kandungan polifenol didalam teh, terutama tannin akan berikatan dengan $\mathrm{Fe}$ membentuk senyawa komplek.

Tanin merupakan suatu senyawa polifenol yang berasal dari tumbuhan, berasa pahit dan kelat, yang bereaksi dengan dan menggumpalkan protein, atau berbagai senyawa organik lainnya termasuk asam amino dan alkaloid. Pengertian tanin meluas, mencakup aneka senyawa polifenol berukuran besar yang mengandung cukup banyak gugus hidroksil dan gugus lain yang sesuai (misalnya karboksil) untuk membentuk perikatan kompleks yang kuat dengan protein dan makromolekul yang lain (Chung, K. T at al (1998). Tanin merupakan antioksidan berjenis polifenol-yang mencegah atau menetralisir efek radikal bebas yang merusak yang menyatu dan mudah teroksidasi menjadi asam tanat. Tanin dikenal juga sebagai zat samak untuk pengawetan kulit, yang merupakan efek tanin yang utama sebagai adstringensia yang banyak digunakan sebagai pengencang kulit dalam kosmetik (Setyamidjaja, 2000).

Di Indonesia, aneka produk teh kemasan banyak dijumpai. Hampir semua jenis rumah makan, bakso, mie ayam atau restoran-restoran cepat saji, menyajikan beberapa produk teh kemasan dengan berbagai merk, karena teh merupakan minuman yang paling banyak dikonsumsi didunia selain air putih (Besral dkk, 2007). Banyak manfaat yang didapat oleh tubuh dari meminum teh, salah satunya adalah sebagai antioksidan yang di percaya dapat mengusir radikal bebas sehingga dapat menurunkan resiko serangan jantung dan stroke. Namun tanin yang terkandung di dalam teh memberikan efek yang kurang baik bagi kesehatan. Sebagaimana pada penelitian ini bahwa minuman teh seluruhnya meyerap larutan $\mathrm{Fe}$ yang ditambahkan. Dengan hal ini maka tanin berperan dalam pengurangan daya serap zat besi (Iron/Fe). Selain itu, tanin diketahui dapat berikatan dengan protein dan mineral sehingga protein dan mineral menjadi tidak dapat digunakan oleh tubuh. Hasil penelitian yang dilakukan Kaltwasser, et al. (1998).

Pada umumnya, tanpa disadari masyarakat mempunyai kebiasaaan mengonsumsi minuman teh pada saat yang bersamaan dengan makan. Hal ini sebagaimana 
hasil dari quesioner didapatkan dari 50 orang responden, sebanyak 39 orang (78\%) mengkonsumsi teh kemasan setelah makan dan 11 orang (22\%) menkonsumsi teh kemasan hanya ketika kondisi haus. Dengan demikian penyerapan besi pada makanan akan menjadi terhambat. Terhambatnya penyerapan $\mathrm{Fe}$ pada tubuh dapat menyebabkan kekurangan zat besi dalam tubuh atau mengalami anemia defisiansi besi. Secara umum semua jenis teh mengandung tanin baik teh yang dalam kemasan ataupun teh yang diseduh, dengan demikian perlunya menghindari konsumsi teh setelah makan yang mengandung Fe.

Anemia defisiensi besi (ADB) adalah anemia yang disebabkan oleh kurangnya besi yang diperlukan untuk sintesis hemoglobin. Selain dibutuhkan untuk pembentukan hemoglobin yang berperan dalam penyimpanan dan pengangkutan oksigen, zat besi juga terdapat dalam beberapa enzim yang berperan dalam metabolism oksidatif, sintesis DNA, neurotransmitter dan proses katabolisme yang dalam bekerjanya membutuhkan ion besi. Dengan demikian, kekurangan besi mempunyai dampak yang merugikan bagi pertumbuhan dan perkembangan anak, menurunkan daya tahan tubuh, menurunkan konsentrasi belajar dan mengurangi aktivitas kerja (Dewi dan Mustika, 2012).

Upaya Penanggulangan anemia gizi dapat dilakukan dengan beberapa cara, pertama adalah pemberian suplementasi tablet zat besi. Cara kedua adalah melalui fortifikasi bahan makanan dengan zat besi seperti garam dapur, tepung terigu, dan penyedap masakan. Berikutnya adalah membatasi pembuangan zat besi dari tubuh yang bersifat patologis. Beberapa jenis penyakit, termasuk penyakit kecacingan akan memperbesar pengeluran zat besi dari tubuh atau menghambat peneyerapan zat besi yang terkandung dalam makanan. Bila penyakit-penyakit tersebut dapat teratasi, maka akan mengurangi timbul nya anemia zat besi (Dewi dan Mustika, 2012).

Berdasarkan nilai serapan, teh MT yang memiliki serapan $\mathrm{Fe}$ paling banyak dibandingkan dengan teh kemasan lainnya. Jika dilihat dari komposisi atau jenis teh yang di kandungnya teh MT mengandung jenis teh oolong, hal ini berbeda dengan teh kemasan lainnya yang mengandung teh hijau atau teh melati. Teh oolong merupakan teh yang dibuat semi fermentasi yaitu daun teh hijau yang sudah dipanaskan atau diuapkan di dilakukan fermentasi tetapi tidak sempurna. Selain teh hijau dan teh oolong adalagi yaitu jenis teh hitam. Teh hitam adalah teh hijau yang difermentasi dengan sempurna. (Hartoyo, 2003). Dengan demikian teh oolong merupakan teh pertengahan antara teh hijau sebelum menjadi teh hitam.

Berdasarkan penelitian terdahulu telah diketahui bahwa teh hitam dapat menurunkan penyerapan zat besi sebesar 70\% (Kaltwasser et.al 1998). Jenis teh yang penyerapan zat besi paling kuat adalah teh hitam dibandingkan dengan jenis teh lainnya (Hurrel, et.al 1999). Thankachan, et.al (2008) menemukan perbedaan penurunan penyerapan zat besi antara mengkonsumsi 1 cangkir dengan mengkonsumsi 2 cangkir teh. Penelitian yang dilakukan Wardiyah, dkk (2014), terdapat perbedaan serapan atau reaksi Fe secara in vitro pada teh hitam apabila dibandingkan dengan teh hijau. Berdasarkan hal ini maka disaat akan menkonsumsi minuman teh perlunya memperhatikan komposisi atau jenis teh yang dikandungnya untuk menghindari gangguan serapan Fe ketika dikonsumsi.

Selain teh, kopi, garam kalsium dan magnesium dapat mengikat $\mathrm{Fe}$ sehingga mengurangi jumlah serapan Fe. Oleh karena itu, tablet Fe sebaiknya dikonsumsi bersamaan dengan makanan yang banyak membantu penyerapan, dan makanan yang mengikat Fe sebaiknya dihindarkan atau, karena kadar tablet besi terbukti dapat menurunkan kadar seng dalam serum (Arisman, 2004 ; Curtis, 1999).

Simpulan dari penelitan ini adalah: Minuman teh kemasan TG merupakan teh yang menyerap $\mathrm{Fe}$ paling sedikit, yaitu sebesar sebesar 3,72 ppm. Minuman teh kemasan MT merupakan teh yang menyerap $\mathrm{Fe}$ paling banyak, yaitu sebesar sebesar 37,08 ppm. Terdapat perbedaan serapan berbagai minuman teh kemasan dengan terhadap penambahan larutan Fe.

Saran yang dapat diberikan adalah: Untuk masyarakat sebaiknya tidak mengonsumsi minuman teh bersamaan dengan waktu makan makanan yang mengandung zat besi. Perlunya masyarakat memperhatikan komposisi atau jenis teh yang terkandung dalam teh kemasan. Perlu dilakukan penelitian lanjutan mengenai pengaruh penambahan larutan teh terhadap kadar Ca.

\section{Daftar Pustaka}

Almatsier S, 2009. Prinsip Dasar Ilmu Gizi. PT Gramedia Pustaka Utama, Jakarta

Arisman, 2004. Gizi Dalam Daur Kehidupan: Buku Ajar Ilmu Gizi. EGC Jakarta 
Besral, Meilianingsih L, Sahar J, 2007. Pengaruh Minum Teh Terhadap Kejadian Anemia Pada Usila Di Kota Bandung. Makara, Kesehatan, Vol. 11, No. 1: 38-43.

Chung, K. T., Wong, T. Y., Wei, C. I., Huang, Y. W., \& Lin, Y. (1998). Tannins and human health: a review. Critical reviews in food science and nutrition, 38(6), 421464.

Dewi C dan Mustika NH, 2012. Bahan Pangan,Gizi, Dan Kesehatan. CV Alfabeta, Bandung.

Gibson S. Iron Intake And Iron Status Of Preschool Shildren: Association With Breakfast Cereals, Vitamin C And Meat. Public Health Nutrition, 1999 (2):521528

Hartoyo, Arif. 2003. Teh Dan Khasiatnya Bagi Kesehatan. Kanisius, Jakarta.

Kaltwasser JP, Werner E, Schalk K, Hansen C, Gottschalk R, Seidl C, 1998. Clinical Trial on the Effect of Regular Tea Drinking on Iron Accumulation in Genetic Haemochromatosis. Gut 1998;43:699-704 doi:10.1136/gut. 43.5.699.

Nelson M, Poultert J, 2004. Impact Of Tea Drinking On Iron Status In The UK: A Review. J Hum Nutr Dietet, 17, 43-54.

Soegeng S, Anne L, 2009.Kesehatan Dan Gizi. PT Rineka Cipta, Jakarta.

Setyamidjaja, D. 2000. Teh, Budidaya Dan Pengolahan Pascapanen. Pustaka Pelajar, Yogyakarta.

Thankachan P, Walezyk T, Muthayya S, Kurpad AV, Hurrel RF 2008. Iron Absorption in Young Indian Women: The Interaction of Iron Status with the Influence of Tea and Ascorbic Acid. Am J Clin Nutr 2008; 87; 881-6.

Wardiyah. H, Yustini Alioes, Dian Pertiwi. 2014. Perbandingan reaksi zat besi terhadap teh hitam dan teh hijau secara invitro dengan menggunakan spektrofotometer. Jurnal Kesehatan Andalas 3(1). 